\title{
Religious Mythology in "Waiting for Godot"
}

\author{
Assist Lecturer. Haider Luaibi Saad
}

\author{
Wassit University... College of Arts... Translation Department
}

\begin{abstract}
"Waiting for Godot" by Samuel Beckett may be considered one of the most famous plays in twentieth century, at the same time it may also be among the most controversial plays. Moreover, being attributed to the absurd theatre, adds ambiguity to its content. In this type of drama, there is not a real plot, so it is very difficult to the viewer to understand what is exactly meant by the writer of the text. The main question that has been discussed by many critics is; who is Godot? "Any interpretation that strives to know who Godot is (or is not), whether he is realistic character, whether he will ever come, whether he has ever come, or even whether he may have come without being recognized (or possibly in disguise) is, if not absolutely wrong, at least not absolutely right" Hutchings ${ }^{(\mathbf{1})}$. Critics are of different views about the character of Godot in this play. Samuel Beckett himself didn't give answer to this question when he was asked. He said that if he knew he would reveal but he claimed that he himself didn't know. Classical works always have the possibility for being understood in different way. This might has been a good reason for Beckett not to reveal the real personality of Godot to make readers and critics think seriously about his characters.
\end{abstract}

This paper is an attempt to give an acceptable interpretation about this character. Depending on religious texts of New Testament, Old Testament and the holy Quran, the researcher is trying to give an approach about the personality of Godot consequently to prove that this character is taken from religious mythologies which are found in Beckett's mind. Revealing that personality of redeemer is referred in all last three religious books will be great evidence that Samuel Beckett was consciously or not, influenced by this idea and tried to criticize it according to his inclination to existential philosophy. So, this paper is divided into two main parts, firstly to prove that there are different hints about waiting for the redeemer in religious books, and second to prove that the author was influenced by these hints. The researcher will prove the first point by citing various texts from holy books that are speaking about the redeemer or related to waiting somebody who will come in certain period of this world, and second point will be proved by observing different items in the play which are related directly to religious characters. The reader will see how Beckett mentions more than three times in his play names of religious characters and this reflect the influence of such things on him.

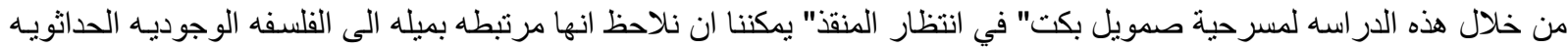

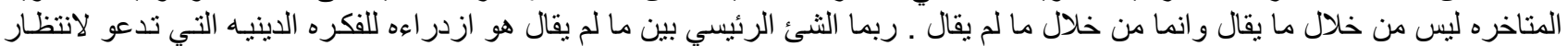

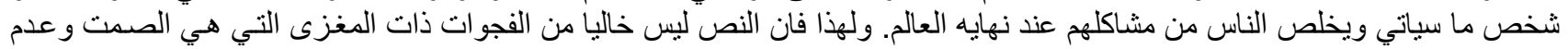

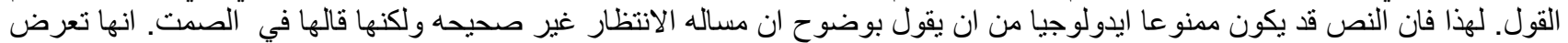

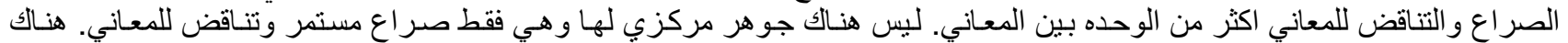

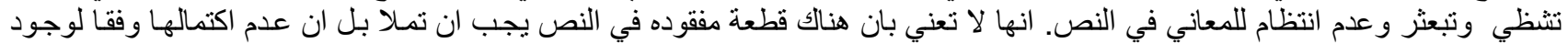

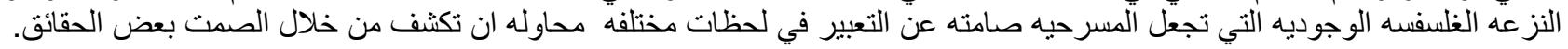

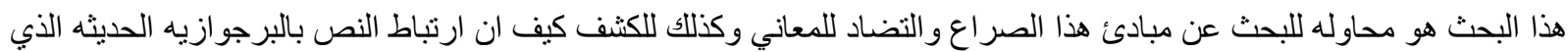

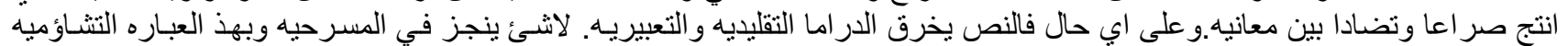

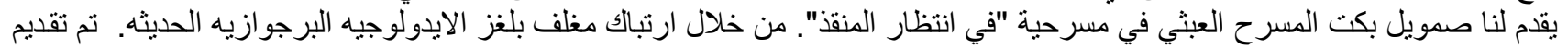

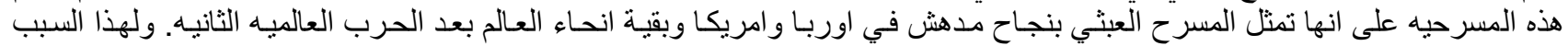

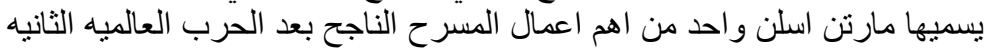

\section{Samuel Beckett's life}

The Becketts were members of the Anglican Church of Ireland. Samuel Beckett was born in Dublin in 1906, his father was quantity surveyor. There is a similarity between him and Shaw, Wilde, and Yeats, he came from the protestant Irish middle class and was, though he later lost his faith, brought up almost Quaker, as he himself once declared ${ }^{(2)}$. It has been supposed that Beckett's interpretation about the problems of being and the identity of the self might have come from the Anglo-Irishman's inevitable and particular concern with finding an accurate answer to the question who am I? In spite of there may be a grain of truth in this, it is surely far from providing a perfect explanation for the deep existential anguish which is the keynote of Beckett's work and which clearly originates in levels of his personality far deeper than its social surface ${ }^{(3)}$.

He had entered Trinity College, Dublin in 1923, where he read French and Italian. He received his Bachelor of Art degree in 1927. He had got a good chance when his university nominated him as its representative in a traditional exchange of lecturers with the famous Ecole Normale Superieure, 
in Paris. In Paris became in touch with James Joyce and soon became a member of his circle, participating, at the age of exactly twenty three, in the brilliant opening essay of that strange book, a collection of twelve articles by twelve apostles. These are the articles of his faith that Beckett has put into practice in his own life works as a writer with an uncompromising consistency almost terrifying in its purity.

At the age of twenty four, Beckett seemed to be launched on a safe and brilliant academic and literary career. He obtained his master of arts degree and In 1930, Beckett returned to Trinity College as a lecturer ${ }^{(4)}$.

As for such person like Beckett who thought that habit and routine was the cancer of time, social intercourse would be surely a mere illusion and the artist's life definitely a life of solitude. The daily grind of university lecturer's work must have appeared unbearable for him and after only four terms at Trinity college he had decided to stop this work. He had left his career and cut himself loose from all routine and social relationships. This amount of his biography gives us an idea about his inclination toward isolated life and about the influence of religion on him $^{(5)}$.

\section{Religion and religious perspective}

Religion represents the main part of life for the greatest majority of people all over the world and remarkably touches the core of their lives. It may orientate lives of people into different ends which extent even to sacrifice themselves and die for religious issues, so explaining the meaning of religion is important. There are three definitions of religion mentioned in oxford dictionary. "The belief in the existence of God or Gods; and the activities that are connected with the worship of them", "One of the systems of faith that are based on the belief in the existence of particular God or Gods"," A particular interest or influence that is very important in your life"(6). Samuel Beckett's religion is Christianity, so it is important to understand what dose religionmean according to Christianity and how might this sense affecte him. The Gospel thought, as Pastor Keller says:

"The universe is not empty, but created by a good and heavenly Father. It is a universe

that is both filled with good things to enjoy, as well as moral laws that give structure to our lives. But the chief goal and aim of life is neither enjoying the good gifts, nor obeying the laws, but in knowing and being known by the Creator who made the universe. When we try to fill our lives with created things and not the Creator, we end up empty and burned out".

Islam is the second religion in the world, so an explanation about religion due to Islamic point of view is important to be mentioned. Grand Ayatollah Sayyid Kamal al-Haideri states " Religion means divine system revealed by prophets and messengers of God in order to make human

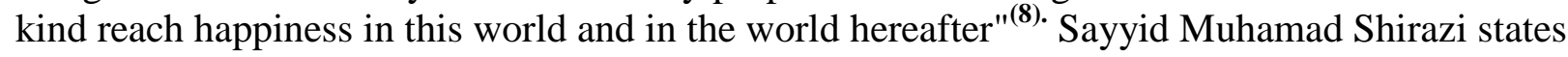

"All religions share the same common essence and their differences lie in details and certain characteristics which have developed according to the advancement of human race(9).God high exalted had stated this fact in the holy Quran: "And in their footsteps we sent Jesus the son of Mary, confirming the law that had come before him; we sent him with the Gospel: therein was guidance and light, and confirmation of the law that had come before him, a guidance and an admonition to those who fear Allah.

From these definitions of religion mentioned above, the meaning of religion according to both Christianity and Islam is a system that aims to give people happiness in this world and in the world hereafter. Confronting many difficulties to achieve happiness in this world, religions try to give another hope about reaching happiness. Waiting for the savor, which is the main idea of this assignment, is a solution suggested by religions to achieve happiness.

\section{Myth and Mythology}

Myth is a kind of story or rudimentary narrative sequence, normally traditional and anonymous, through which given culture ratifies its social customs or accounts for the origins of human and natural phenomena, usually in supernatural or boldly imaginative terms

"Myths feature supernatural episodes that seek to explain natural phenomena in order to give humans some kind of special perceptions in a more cosmic level."(11). It amplifies human culture and 
society to a superhuman or godly level. Although myths have such a nature, they are still accepted as both true and sacred.

By contrast, mythology is a collection of several or many myths that usually belong to a group of people or culture. In this connection, mythologies often address the issues of that particular group of people (their history, gods, and ancestry).

Another interpretation regarding mythology is defining it as "the study of myths" (12). Therefore, one who is studying or learning about myths may most likely be studying the field of mythology as a whole. Some specific sub branches of mythology are comparative mythology and Greek mythology. The former deals with finding the connection present between myths coming from varied cultures whereas; the latter is, obviously, the study of the popular myths of Ancient Greece.

Myth criticism, which became common and spread in the 1950s and 1960s, is less interested in the certain features of a given work than in those specific qualities of its narrative structure or symbolism that seem to relate it to ancient myths and religions. Moreover, recently "myth criticism has been broadly dismissed as a form of reductionism that neglects cultural and historical differences as well as the specific properties of literary works "(13).

\section{Absurd Theatre}

"Waiting For Godot" is one of the most prominent plays of absurd theatre, so it is important to shed a light on this idiom. According to oxford literary term " It derived from the existentialism of Albert Camus, and often applied to the modern sense of human purposelessness in a universe without meaning or value. The critic Martin Essline coined the phrase ' theatre of the absurd' in 1961 to refer to a number of dramatists of the 1950s (led by Samuel Beckett and Eugene Ionesco) whose works evoke the absurd by abandoning logical form, character, and dialogue together with realistic illusion. The classic work of absurd theatre is Beckett's 'Waiting for Godot' ${ }^{\text {(14). }}$ Martin Esslin has explained the meaning of absurd theatre " Absurd originally means 'out of harmony' in a musical context. Hence its dictionary definition: out of harmony with reason or propriety; incongruous, unreasonable, illogical. In common usage, 'absurd' may simply mean 'ridiculous', but this is not the sense in which Camus uses the word and in which it is used when we speak of the theatre of the absurd. Ionesco defined his understanding of the term as follows:

" Absurd is that which is devoid of purpose...cut off from his religious, metaphysical and transcendental roots, man is lost; all his actions become sensless, absurd, useless."(15) This sense of metaphysical anguish at the absurdity of the human condition is, broadly speaking, the theme of the plays of Beckett. Theatre of the absurd strives to express its sense of the senselessness of the human condition and the inadequacy of the rational approach by the open abandonment of rational devices and discursive thought. It goes step further in trying to achieve a unity between its basic assumption and the form in which these assumptions are expressed. It is this striving for an integration between the subject matter and the form in which it is expressed that separates the theatre of the absurd from the Existentialist theatre. Dramatists of the absurd are trying by instinct and by intuition rather than by conscious effort to overcome and resolve inner contradictions in human being."(16)

\section{Symbolism of Waiting}

The principle of waiting is a substantial and important aspect of the human condition. Throughout our lives we perpetually hope to get rid of our problems and expect something might help us. Many critics are of the opinion that the word "Waiting" has religious trend in this play. "Waiting for Godot is concerned with the hope of salvation through the workings of grace seems clearly established both from Beckett's own evidence and from the texts itself. Does this however, mean that it is a Christian or even that it is a religious play? There have been a number of very ingenious interpretations."(17) 
There are many religious texts which assure the importance of waiting, here are some examples. The first command given by Jesus to his disciples is: "Do not leave Jerusalem, but wait" $(1: 4)^{(18)}$.

'Take Abraham, for example. God promised to give him an heir, yet he and his wife Sarah had to wait 25 years before God's promise was fulfilled. Or take Moses. God called him to be Israel's deliverer, but let him wait for 40 years in Midian before going back to Egypt. Before God led the people of Israel into the Promised Land, Israel had to wait for 40 years while an unfaithful generation perished. Before Paul's life and identity were transformed, he was purblind and made to wait for three days before regaining his sight. And then there is Jesus, very God in human flesh, who waited about three decades before entering into public ministry' (19).

So, in this play the central theme is waiting and we can see easily that this theme is more important than any character, "whether Godot is meant to suggest the intervention of a supernatural agency, or whether he stands for a mythical human being whose arrival is expected to change the situation, or both of these possibilities combined, his exact nature is of secondary importance. The subject of the play is not Godot but waiting, the act of waiting as an essential and characteristic aspect of the human condition".(20)

\section{Waiting for the Savior}

The notion of waiting for the savior is existing in all religions, so this may affect Samuel Beckett whose family are members of the Anglican Church. This fact has been mentioned in The old Testament, The New Testament and the Holy Quran.

According to the Bible

"A shoot will come up from the stump of Jesse; from his roots a branch will bear fruit. The spirit of the Lord will rest on him- the spirit of wisdom and of understanding, the spirit of counsel and power, the spirit of knowledge and of the fear of the Lord- and he will delight in the fear of the Lord. He will not judge by what he sees with his eyes, or decide by what he hears with his ears; but with righteousness he will judge the needy, with justice he will give decisions for the poor of the earth. He will strike the earth with the rod of his mouth; with the breath of his lips he will slay the wicked. Righteousness will be his belt and faithfulness the sash around his waist. The Woolf will live with the lamb, The leopard will lie down with the goat, the calf and the lion and the yearling together; and the lion will eat straw like the ox. The infant will play near the hole of the copra, and the young child put his hand into the viper's nest. They will neither harm nor destroy on all my holy mountain, for the earth will be full of the knowledge of the Lord as the waters cover the sea. In that day the root of Jesse will stand as a banner for the peoples, the nations will rally to him and his place of rest will be glorious"(21).

It is clear from this text chosen from The Old Testament that the Lord promised Jewish people to send them a holy Spirit from him to give them glorious life in which even animals can live peacefully together. This text proves that the religious myth of waiting for somebody who will come to help poor people is exist in the main religious books. In the same way in the New Testament

"The second woe has passed; the third woe is coming soon. The seventh angel sounded his trumpet, and there were loud voices in heaven, which said .The kingdom of the world has become the kingdom of our Lord and of his Christ, and he will reign for ever and ever"'(22).

"A great and wondrous sign appeared in heaven: a woman clothed with the sun, with the moon under her feet and crown of twelve stars on her head. She was pregnant and cried out in pain as she was about to give birth. She gave birth to a son, a male child, who will rule all the with an iron scepter. And her child was snatched up to God and to His throne. The woman fled into the desert to a place prepared for her by God, where she might be taken care of for 1260 days"(23).

In the holy Quran there are many verses refer to the fact of salvation by waiting savior and there are many written books about this idea especially by Shia denomination. One of these verses

"And certainly we wrote in the book after the reminder that as (as for) the land, my righteous servants shall inherit it"(24).

So this verse refers clearly to the end of life and states that good people will rule the earth. Another verse in this regard is

"Allah has promised to those of you who believe and do good that He will most certainly make them rulers in the earth as he made rulers those before them, and that He will most certainly establish for them their religion which He has chosen for them, and that He will most 
certainly, after their fear, give them security in exchange; they shall serve Me, not associating aught with Me; and whoever is ungrateful after this, these it is who are the transgressors"(25).

This verse refers that Allah has promised the good people to make them successors in the earth and make their life very comfortable. Again it is mentioned in another verse

"And We desired to bestow a favor upon those who were deemed weak in the land, and to make them the Imams, and to make them the heirs. And to grant them power in the land"(26).

\section{Waiting for Godot}

It is clear that "Waiting for Godot" is concerned with the hope of salvation. This fact is established both from Beckette's own evidence and from the text itself.

" Vladimir's and Estragon's waiting is explained as signifying their steadfast faith and hope, while Vladimir's kindness to his friend, and the two tramps mutual interdependence, are seen as a symbols of Christian charity. But these religious interpretations seem to overlook a number of essential features of the play such as its constant stress on the uncertainty of the appointment with Godot, Godot's unreliability and irrationality, and the repeated demonstration of the futility of the hopes pinned on him. The act of Waiting for Godot is shown as essentially absurd."(27)

In support of the Christian interpretation, it might be argued that Vladimir and Estragon, who are waiting for Godot, are shown as clearly superior to Pozzo and Lucky, who have no appointment, no objective, and are wholly egocentric, wholly wrapped up in their sadomasochistic relationship. Is it not their faith that puts the two tramps on to higher plane?

It is evident that, in fact, Pozzo is naively overconfident and self -centred. "Do I look like a man that can be made to suffer?" he boasts. Even when he gives a soulful and melancholy description of the sunset and the sudden falling of the night, we know he doesn't believe the night will ever fall on him; he is not concerned with the meaning of what he recites, but only with its effect on the audience.

Here we will state some quotations from the text of "Waiting for Godot"

to prove that the writer is influenced by the idea of the savior.

"VLADIMIR: Did you ever read the Bible?

ESTRAGON: The Bible ... (He reflects.) I must have taken a look at it.

VLADIMIR: Do you remember the Gospels

ESTRAGON: I remember the maps of the Holy Land. Coloured they were. Very pretty. The Dead Sea was pale blue. The very look of it made me thirsty. That's where we'll go, I used to say, that's where we'll go for our honeymoon. We'll swim. We'll be happy.

VLADIMIR: You should have been a poet.

ESTRAGON: I was. (Gesture towards his rags.) Isn't that obvious?

Silence.

VLADIMIR: Where was I . . How's your foot?

ESTRAGON: Swelling visibly.

VLADIMIR: Ah yes, the two thieves. Do you remember the story?

ESTRAGON: No.

VLADIMIR: Shall I tell it to you?

ESTRAGON: No.

VLADIMIR: It'll pass the time. (Pause.) Two thieves, crucified at the same time as our Saviour. One- 
ESTRAGON: Our what?

VLADIMIR: Our Saviour. Two thieves. One is supposed to have been saved and the other ... (he searches for the contrary of saved) ... damned.

ESTRAGON: Saved from what?

VLADIMIR: Hell.

ESTRAGON: I'm going. He does not move.

VLADIMIR: And yet ... (pause) ... how is it -this is not boring you I hope- how is it that of the four Evangelists only one speaks of a thief being saved. The four of them were there -or thereabouts- and only one speaks of a thief being saved. (Pause.) Come on, Gogo, return the ball, can't you, once in a way?

ESTRAGON: (with exaggerated enthusiasm). I find this really most extraordinarily interesting.

VLADIMIR: One out of four. Of the other three, two don't mention any thieves at all and the third says that both of them abused him.

ESTRAGON: Who?

VLADIMIR: What?

ESTRAGON: What's all this about? Abused who?

VLADIMIR: The Saviour.

ESTRAGON: Why?

VLADIMIR: Because he wouldn't save them.

ESTAGON: From hell?

VLADIMIR: Imbecile! From death.

ESTRAGON: I thought you said hell.

VLADIMIR: From death, from death."(28).

In this text chosen from Act one of "Waiting for godot" the reference to the Bible is clear and also to the name of the savior. The author here speaks about the story of the three thieves mentioned in the Gospel. "The theme of the two thieves on the cross, the theme of the uncertainty of the hope of salvation and the fortuitousness of the bestowal of grace, does indeed pervade the wholly play."(29) " The fortuitous bestowal of grace, which passes human understanding, divides mankind into those that will be saved and those that will be damned."(30)

" ESTRAGON: What exactly did we ask him for?

VLADIMIR: Were you not there?

ESTRAGON: I can't have been listening

VLADIMIR: Oh ... Nothing very definite.

ESTRAGON: A kind of prayer.

VLADIMIR: Precisely.

ESTRAGON: A vague supplication.

VLADIMIR: Exactly" 
This conversation between Estragon and Vladimir reveals something about the character of Godot. They asked him to do to them "A kind of prayer" and " A vague supplication". This ensures the religious nature of this person and supports our idea about mythological interpretation of this drama.

When Pozzo asked Lucky to think loudly, he said an address in which he referred to some religious and mythological thoughts. According to his existentialism point of view Beckett try to depict his thought about religion ridiculously " Given the existence as uttered forth in the public works of Puncher and Wattmann of a personal God quaquaquaqua with white beard quaquaquaqua outside time without extension who from the heights of divine apathia divine athambia divine aphasia loves us dearly with some exceptions for reasons unknown but time will tell and suffers like the divine Miranda with those who for reasons unknown but time will tell are plunged in torment plunged in fire whose fire flames if that continues and who can doubt it will fire the firmament that is to say blast hell to heaven" ${ }^{\text {(32). }}$

"VLADIMIR: But you can't go barefoot!

ESTRAGON: Christ did.

VLADIMIR: Christ! What has Christ got to do with it. You're not going to compare yourself to Christ!

ESTRAGON: All my life I've compared myself to him.

VLADIMIR: But where he lived it was warm, it was dry!

ESTRAGON: Yes. And they crucified quick." (33)

Again, the author speaks blankly about the Christ and makes comparison between one of the main characters of his drama with the way in which the Christ was living and this reflects that the image of the Christ the Savior is present strongly throughout this play.

\section{Conclusion}

By this study of Samuel Beckett's play "Waiting for Godot", we can observe it is closely tied to existentialism ideology of the late modernism, not by what it says rather by what it doesn't say. Perhaps the main thing among what it doesn't say is to scorn the religious idea of waiting somebody who will come to help people at the end of the world. That is why; its text is not empty from significant gaps, silences and non-saids. Therefore, its text is ideologically forbidden to say in trying to tell the truth. In this regard, it is incomplete because it was trying to say that the idea if waiting is not truth but it couldn't do this clearly. It displays conflict and contradiction of meanings rather than unity between meanings. There is no central essence to it but it is just a continuous conflict and contradiction of meanings. There are scattered, dispersed, diverse and irregular meanings within the text. It does not mean that there is a piece missing in the text of "Waiting for Godot" to fill in. However, its incompletion is due to the presence of the late modernist existentialist ideology, which silences it at certain points to reveal the truth.

This paper attempts to seek out the principle of its conflict and contradiction of meanings as well as to display how the text's relations to the late modernist bourgeois ideology produce conflict and contradiction of its meanings. However, the play has ahistorical prospect, predisposition towards the perception of absurdity, uncertainty and futility of waiting and nihilism of human existence. It evinces a numerous signs of binary oppositions and most important of all the violation of the conventional drama and direction of expressionism, surrealism, existentialism, stream of consciousness technique and symbolic and allegorical illustration of the dramatic movement of the Theatre of the Absurd. "Nothing to be doneece (Beckett Samuel, 1956, p.9) with this pessimist utterance, Samuel Beckett introduces the absurd world of "Waiting for Godot," a confusion that is shrouded in the enigma of the late modernist bourgeois ideology. This play has been performed as a drama of the absurd with astonishing success in Europe, America and the rest of the world in post 
second world war era. For this reason, Martin Esslin calls it, "One of the successes of the post-war theatre" (Esslin, Martin, 1980, p.3).

Notes

1. Hutching, Samuel Beckett's Waiting For Godot: a reference Guide, London, 2005,

2. .Harold Hoboson, Samuel Beckettt, Dramaist of the year, London:John Calder, 1956, p.57.

3. Samuel Beckett, Murphy(New York: Groe press,1963,p.269

4. Beckett, More Pricks than Kicks, London:Chatto \& Windus, 1942, p.

43.

5. Martin Esslin, The theatre of the absurd, London,1968,p.33

6. Oxford dictionary, London, eight edition,2006, p.1287.

7. Intrnet site.

8. Kamal al-haideri, Philosophyof Religion, Qum, first edition, p14.

9. Muhammad al-Shirazi, What is Islam, alnajaf, 2007, p 2.

10. The holy Quran, translated by Hamid Shakri, Qum, suratal Maaia,46, 47.

11.http://www.differencebetween.net/language/words-language/difference-between-myth-and-mythology. Retrieved on 15/11/2016. P.26

12. Chris Baldick, Literary Terms, United states, 2008,p.218.

13.ibid, p.217.

14. Chris Baldick, Oxford dictionary of literary terms,united states, 2008,p1.

15. Eugene Ionesco, Dans les arms de la ville, Paris, no 20, 1957

16. Martin Esslin, The theatre of the absurd, London,1968,p.23.

17.ibid,p.55.

18. New Testament, ISBN, third print, 2002, Acts,1.

19. Jeff Strong, Waiting is not something to be avoided or overcome, but to be embraced. / JUNE 24, 2015, essay on web.

20. Martin Esslin, The theatre of the absurd, London,1968,p.49

21. The Bible, ISBN, third print 2002, great britian, Isaiah 11, p.1053.

22. ibid, Revelation 11, p.1868.

23.ibid, Revelation 12, p.1869.

24. Holy Quran, translated by Hamid Shakiri, Qum ,first edition, b 21 (the prophets),105.

25. ibid, 24 The light (al-Nur), 55.

26.ibid,28 the Narratives (al-Qasas), 5,6.

27. Martin Esslin, The theatre of the absurd, London,1968,p.56.

28.Samuel Beckett, Waiting for Godot, London,third edition,1974, p.10

29. Martin Esslin, The theatre of the absurd, London,1968,p.53

30. ibid, p54.

31. Samuel Beckett, Waiting for Godot, Lonon, third edition, 1974, p.12.

32. ibid, p.37

33.ibid, p. 47 